\title{
PENGATURAN PEMBERIAN HAK GUNA BANGUNAN DI ATAS TANAH HAK MILIK
}

\author{
Oleh : \\ Rizki Kurniawan*, Amalia Zulfa Salsabil** \\ * Fakultas Hukum, Universitas Gresik \\ Email : rizkikurniawansgmh@gmail.com \\ ** Fakultas Hukum, Universitas Gresik \\ Email : azulfa47@gmail.com
}

\begin{abstract}
ABSTRAK
Tanah merupakan salah satu unsur utama dalam kehidupan manusia dan merupakan salah satu sumber kekayaan alam yang memiliki fungsi penting bagi pembangunan perekonomian masyarakat Indonesia. Tanah diperlukan antara lain untuk tempat tinggal maupun untuk kegiatan usaha yang semakin bervariasi sesuai dengan perkembangan ekonomi, sosial, budaya dan teknologi. Selain itu, tanah merupakan salah satu bagian dari kebutuhan hidup manusia yang mendasar. Manusia hidup dan berkembang biak, serta melakukan aktivitas diatas tanah, sehingga setiap saat manusia berhubungan dengan tanah. Dengan semakin meningkatnya kebutuhan akan tanah, maka tidakmenutup kemungkinan akan menimbulkan konflik di bidang pertanahan. Tanah adalah benda tidak bergerak/benda tetap karena sifatnyatidak dapat dipindah-pindahkan.Dari latar belakang tersebut maka timbul permasalahan, Bagaimana pengaturan hukum tentang hak dan kewajiban pemegang Hak Guna Bangunan dan Hak Milik dalam hukum pertanahan Indonesia dan Bagaimana Pelaksanaan Pengaturan hukum Pemberian Hak Guna Bangunan Diatas Tanah Hak Milik.

Hasil Penelitian ini menunjukkan bahwa Pengaturan hukum tentang hak pemegang Hak Guna Bangunandiatur dalam pasal 32 Peraturan Pemerintah Nomor 40 Tahun 1996. Sementara kewajiban pemegang Hak Guna Bangunandiatur dalam Pasal 30 Peraturan Pemerintah Nomor 340 Tahun 1996. Sedangkan Pengaturan hukum tentang Hak PemegangHak Milik dalam hukum pertanahan Indonesia diatur dalam pasal 4 ayat (2) UUPA, dan kewajiban pemegangHak Milik dalam hukum pertanahan Indonesia diatur dalam pasal 15 UUPA.
\end{abstract}

Kata Kunci: Bangunan;Hak; Pemberian; Pengaturan; Tanah. 


\begin{abstract}
Land is one of the main elements in human life and is a source of natural wealth which has an important function for the economic development of Indonesian society. Land is needed, among others, for residence and for business activities which are increasingly varied according to economic, social, cultural and technological developments. In addition, land is one of the basic necessities of human life. Humans live and reproduce, and carry out activities on the ground, so that every time humans come into contact with the land. With the increasing need for land, it is possible to cause conflicts in the land sector. Land is immovable object / fixed object because it cannot be moved. From this background, the problem arises, How are the legal arrangements regarding the rights and obligations of Building Use Rights and Property Rights holders in Indonesian land law and how are the legal arrangements for granting Building Use Rights Above Freehold Land.

The results of this study indicate that the legal arrangements regarding the rights of building use rights holders are regulated in Article 32 of Government Regulation Number 40 of 1996. Meanwhile, the obligations of holders of Building Use Rights are regulated in Article 30 of Government Regulation Number 340 of 1996. While Indonesian land law is regulated in article 4 paragraph (2) of the UUPA, and the obligations of property rights holders in Indonesian land law are regulated in article 15 of the UUPA.
\end{abstract}

Keywords: Building; Rights; Giving; Arrangement; Land. 


\section{A. Pendahuluan}

\section{A. Latar Belakang}

Tanah merupakan salah satu unsur utama dalam kehidupan manusia dan merupakan salah satu sumber kekayaan alam yang memiliki fungsi penting bagi pembangunan perekonomian masyarakat Indonesia. Tanah diperlukan antara lain untuk tempat tinggal maupun untuk kegiatan usaha yang semakin bervariasi sesuai dengan perkembangan ekonomi, sosial, budaya dan teknologi. Selain itu, tanah merupakan salah satu bagian dari kebutuhan hidup manusia yang mendasar.Manusia hidup dan berkembang biak, serta melakukan aktivitas diatas tanah, sehingga setiap saat manusia berhubungan dengan $\operatorname{tanah}^{1}$

Dengan semakin meningkatnya kebutuhan akan tanah, bahwa akan ada peluang akan menimbulkan perselisihan pada bidang pertanahan. Oleh karenanya diperlukan peraturan yang bisa mengakibatkan acuan sehingga terciptalah suatu kepastian hukum pada bidang pertanahan. memberlakukan UU Nomer 5 Tahun 1960 tentang Peraturan Dasar Pokok-Pokok Agraria yakni lebih dikenal dengan sebutan UndangUndang Pokok Agraria (untuk selanjutnya disingkat UUPA).

Dengan aktifnya UUPA, timbulnya perubahan fundamental berkenaan hukum agraria di Indonesia, mengutamakan dibidang hukum pertanahan. Perubahan yang mendasar dan fundamental dimaksud sebab sudah timbul perubahan baik yaknistuktur perangkat hukum, berhubungan konsepsi yang melandasi ataupun isinya yang menyatakan pada bagian yang berdasarkan UUPA layakagar sesuai

${ }^{1}$ Marihot Pahala Siahaan, Bea Perolehan Hak Atas Tanah dan Bangunan, Raja Grafindo Persada, Jakarta, 2003, h.1. bersama kepentingan rakyat Indonesia bisa memenuhi juga keperluannya menurut permohonan zaman.

Tanah adalah benda tidak bergerak/benda tetap karena sifatnyatidak dapat dipindahpindahkan.Yang dapat dipindahpindahkan atau berpindah ialah hak-hak atas berupa tanah. Pemindahan ataupun peralihan hak atas tanah ini perluperlu dibuktikan bersama akta otentik.Lantas, perlu dipertanyakan mampukah sertipikat dijadikan sebagai alat yang bernilai sebagai pengaman bila timbul permasalahan tentang tanah. Untuk itu perlu diikuti kewajiban mendaftarkan dan pencatatan perubahan-perubahan yang terjadi dikemudian hari.

Pendaftaran tanah selain berfungsi untuk melindungi si pemilik, juga berfungsi untuk mengetahui status sebidang tanah, siapa pemiliknya, apa haknya, berapa luasnya, untuk apa dipergunakan dan sebagainya. Dengan pengaturan Hak Guna Bangunan Di atas Tanah Hak Milik maka dapat meminimalisir praktik monopoli tanah, karena pemberian Hak Guna Bangunan hanya didasarkan pada perjanjian pemberian Hak Guna Bangunan Diatas Tanah Hak Milik yang dapat dibatasi dengan waktu tertentu, sehingga pemegang masih tetap mempunyai hak atas tanah tersebut.

Terkait dengan tujuan pendaftaran tanah untuk menyediakan informasi, berarti hasil dari pelaksanaan pendaftaran tanah tersebut dapat dijadikansebagai data-base bagi instansi pemerintah yang memerlukan informasi mengenai keadaan dan potensi bidangbidang tanah yang sudah bersertipikat, seperti instansi perpajakan, pemerintah daerah dan pihak-pihak lain yang berkepentingan. Tertib administrasi dalam pendaftaran tanah dimaksudkan bahwa seluruh berkas-berkas di Kantor Pertanahan harus sudah tersimpan 
dengan baik dan teratur sehingga memudahkan untuk mencari suatu data yang diperlukan, terbukti dari adanya sejumlah buku-buku yang tersedia dalam menunjang pendaftaran tanah tersebut. Begitu pentingnya pelaksanaan asas mutakhir yang bertujuan untuk pemeliharaan data pertanahan, atau dengan kata lain menentukan data pendaftaran tanah, secara terus-menerus dan berkesinambungan, sehingga data yang tersimpan di Kantor Pertanahan, selalu sesuai dengan keadaan nyata di lapangan.

Pendaftaran tanah perlu disertai pula dengan pelaksanaan administrasi yang baik, yaitu meliputi pencatatan secara sistematis dan berkesinambungan baik mengenai subjek maupun objek dari hak atas tanahnya tersebut. Hal ini sangat diperlukan untuk memberikan informasi dari keadaan yang sebenarnya, karena semua itu berkaitan dengan tujuan pemerintah untuk mewujudkan catur tertib pertanahan, administrasi pertanahan, penggunaan tanah, pemeliharaan data pertanahan dan lingkungan hidup.

Berdasarkan uraian tersebut di atas, yang menyatakan bagaimana pentingnya peranan asas rechtscadaster dalam pendaftaran tanah, maka penulis tertarik memilih penelitian dengan judul

\section{: "PENGATURAN PEMBERIAN HAK GUNA BANGUNAN DI ATAS TANAH HAK MILIK." \\ B. Rumusan Masalah}

Berdasarkan uraian latar belakang di atas, maka dapatlah dirumuskan permasalahan sebagai berikut :

1. Bagaimana pengaturan hukum tentang hak dan kewajiban pemegang Hak Guna Bangunan dan Hak Milik dalam hukum pertanahan Indonesia ?

2. Bagaimana Pelaksanaan Pengaturan hukum Pemberian Hak Guna Bangunan Diatas Tanah Hak Milik?

\section{Tujuan Penelitian}

Tujuan Penelitian ini adalah untuk memberi arah dalam melangkah sesuai dengan maksud penelitian. Adapun tujuan yang ingin di capai oleh penulis dalam penelitian ini adalah :

1. Penelitian ini bertujuan untuk mengetahui pengaturan hukum tentang hak dan kewajiban pemegang Hak Guna Bangunan dan Hadalam hak pertanahan di Indonesia.

2. Penelitian ini bertujuan untuk mengetahui dan memahami pengaturan hukum pemberian Hak Guna Bangunan di atas Tanah Hak Milik.

\section{Manfaat Penelitian}

Dengan judul tugas akhir seperti di atas, maka manfaat penelitian disusun seperti di bawah ini:

Penelitian ini diharap dapat memberikan manfaat sebagai berikut:

a. ManfaatTeoritis

1. Dapat menambah pengetahuan, pengalaman, dan pemahaman terhadap masalah-masalah yang berkaitan dengan Hukum Agraria, khususnya mengenai pengaturan Hak Guna Bangunan Diatas Tanah Hak Milik.

2. Dapat menambah literatur dan bahan-bahan informasi sebagai pijakan penelitian mengenai pengaturan Hak Guna Bangunan Diatas Tanah Hak Milik.

b. ManfaatPraktis

1. Mengembangkan penalaran, membentuk pola pikir dinamis sekaligus untuk mengembangkan kemampuan penulis dalam mengkritisi persoalan-persoalan hukum.

2. Memberikan masukan pada Kantor Pertanahan mengenai pengaturan Hak Guna Bangunan Diatas Tanah Hak Milik.

\section{E. Metode Penelitian}

A. Jenis Penelitian 
Metode penelitian merupakan hal yang paling penting dalam kegiatan penelitian, untuk mendapatkan data kemudian menyusun, mengolah, dan menganalisisnya. Dalam penelitian ini digunakan metode penelitian yang digunakan penulis adalah sebagai berikut :

Jenis penelitian dalam bentuk penulisan hukum yang bersifat normatif atau doktrinal, yaitu dengan melakukan penelitian terhadap bahan- bahan pustaka atau data-data sekunder yang selanjutnya dikajiuntuk merumuskan hasil penelitian serta menarik kesimpulan dari permasalahan yang diteliti. Penelitian hukum adalah suatu proses untuk menemukan aturan hukum, prinsip-prinsip hukum, maupun doktrin-doktrin hukum guna menjawab isu hukum yang dihadapi. ${ }^{2}$

Penelitian hukum normatif yang nama lainnya adalah penelitian hukum doktrinal yang disebut juga sebagai penelitian perpustakaan ataustudi dokumen karena penelitian ini dilakukan atau ditujukan hanya pada peraturan-peraturan yang tertulis atau bahan-bahan hukum yang lain. ${ }^{3}$

Pada intinya penelitian yang dilakukan dengan cara meneliti bahanbahan pustaka atau data sekunder yang terdiri dari bahanhukum primer, bahan hukum sekunder dan bahan hukum tertier.

\section{B. Metode Pendekatan}

Memecahkan suatu isu hukum melalui penelitian hukum memerlukan pendekatan - pendekatan tertentu sebagai dasar pijakan untuk menyusun argumen yang tepat. Adapun metode

${ }^{2}$ Peter Mahmud Marzuki, Penelitian Hukum, Kencana Prenada Media Group, Jakarta, 2011, h. 35.

${ }^{3}$ Soerjono Soekanto dan Sri Mahmudji, Penelitian Hukum Normatif, Raja Grafindo Persada, Jakarta, 2004, Cetakan ke-8,h. 14. yang digunakan dalam penelitianiniyaitu Pendekatan Perundang - undangan (Statute Approach), Pendekatan Konsep (Conceptual Approach), danPendekatan Perbandingan (Comparative approach).

1. Pendekatan Perundang-Undangan (Statute approach).

Pendekatan ini dilakukan dengan menelaah semua peraturan perundangundangan yang bersangkut paut dengan permasalahan (isu hukum) yang sedang pendekatan dengan cara melakukan terhadap Undang-Undang terutama yang berhubungan dengan Kantor Pertanahan mengenai pengaturan Pemberian Hak Guna BangunanDiatas Tanah Hak Milik diantaranya UndangUndang Nomor 5 Tahun 1960 tentang Peraturan Dasar Pokok-Pokok Agraria, Peraturan Pemerintah Nomor 40 Tahun 1996 tentang Hak Guna Bangunan.

2. Pendekatan Konsep (Conceptual Approach)

Merupakan pendekatan yang beranjak dari pandangan-pandangan dan doktrin-doktrin yang berkembang di dalam ilmu hukum. Pendekatan ini menjadi penting sebab pemahaman terhadap pandangan/doktrin yang berkembang dalam ilmu hukum dapat menjadi pijakan untuk membangun argumentasi hukum ketika menyelesaikan isu hukum yang dihadapi. Pandangan/doktrin memperjelas ide-ide dengan memberikan pengertian-pengertian hukum, konsep hukum, maupun asas hukum yang relevan dengan permasalahan Pengaturan Pemberian Hak Guna Bangunan Diatas Tanah Hak Milik.

3. Pendekatan Perbandingan

(Comparative Approach).

Merupakan pendekatan dengan membandingkan peraturan hukum untuk ataupun putusan pengadilan di suatu Kota dengan peraturan hukum di 
Kota lain (dapat 1 Kota atau lebih), namun haruslah mengenai hal yang sama. Perbandingan dilakukan untuk memperoleh persamaan dan perbedaan di antara peraturan hokum /putusan pengadilan tersebut.

\section{Sumber Bahan Hukum}

Sebagai sumber dalam penelitian hukum normatif, terdiri atas bahan hukum Primer, bahan hukum Sekunder dan bahan hukum Tersier.

1. Bahan Hukum Primer merupakan bahan hukum yang bersifat authoritatif atau bahan hukum yang dikeluarkan oleh pihak yang berwenang dan mengikat umum.Bahan hukum primer terdiri atas ketentuan peraturan perundangundangan dan ketentuan peraturanperaturan lainnya yang berlaku (Hukum Positif) yang berkaitan dengan pokok masalah yang dibahas tidak membatasi adanya ketentuan peraturan-peraturan hukum lainnya yang berkaitan dengan dengan masalah yang akan dibahas.

2. Bahan Hukum Sekunder merupakan buku teks karena buku teks berisi mengenai prinsip-prinsip dasar ilmu hukum dan pandangan-pandangan klasik para sarjana yang mempunyai kualifikasi tinggi.Dalam penelitian ini bahan hukum sekunder yang digunakan adalah buku ilmiah dibidang hukum, makalah, jurnal ilmiah, artikel ilmiah, skripsi/tesis/disertasi.

3. Bahan Hukum Tersier merupakan bahan yang memberikan petunjuk maupun penjelasan terhadap bahan hukum primer dan sekunder.Dalam penelitian ini bahan hukum primer yang digunakan adalah kamus hukum, ensiklopedia, situs internet yang berkaitan dengan pokok pembahasan.

\section{F. PEMBAHASAN}

\section{A. Hak Dan Kewajiban Pemegang} Hak Guna Bangunan

Hak Guna Bangunan adalah hak untuk mendirikan dan mempunyai bangunan diatas tanah/lahan yang bukan miliknya sendiri. Terdapat 3 jenis hak atas tanah yang di atasnya dapat diberikan Hak Guna Bangunan, yakni tanah Negara, tanah dengan Hak Pengelolaan, dan tanah dengan Hak Milik. Hak pemegang Hak Guna Bangunan sangat terbatas karena Hak Guna Bangunan didirikan di atas tanah yang bukan haknya, jadi hanya terjadi sepanjang waktu tertentu. Tidak seperti halnya dengan Hak Milik yang haknya adalah terpenuh di antara hak- hak atas tanah.

\section{Hak Pemegang Hak Guna Bangunan}

Pasal 32 Peraturan Pemerintah Nomor 40 Tahun 1996 menentukan bahwa pemegang Hak Guna Bangunan berhak untuk menguasai dan mempergunakan tanah yang diberikan dengan Hak Guna Bangunan selama jangka waktu tertentu untuk mendirikan dan mempunyai bangunan untuk keperluan pribadi atau usahanya serta untuk mengalihkan hak tersebut kepada pihak lain dan membebaninya.

Hak pemegang Hak Guna Bangunan sangat terbatas karena Hak Guna Bangunan didirikan di atas tanah yang bukan haknya, jadi hanya terjadi sepanjang waktu tertentu. Jangka waktu paling lama 30 tahun dan dapat diperpanjang untuk jangka waktu paling lama 20 tahun.

\section{Kewajiban Pemegang Hak Guna} Bangunan

Kewajiban - kewajiban pemegang Hak Guna Bangunan menurut ketentuan Pasal 30 dan 31 Peraturan Pemerintah Nomor 340 
Tahun 1996. Pasal 31 menegaskan kewajiban pemegang Hak Guna Bangunansebagai berikut :

1. Membayar uang pemasukan yang jumlah dan cara pembayarannya ditetapkan dalam keputusan pemberian haknya;

2. Menggunakan tanah sesuai dengan peruntukannya dan persyaratan yang ditetapkan dalam keputusan dan perjanjian pemberian haknya;

3. Memelihara dengan baik tanah dan bangunan yang ada di atasnya serta menjaga kelestarian lingkungan hidup;

4. Menyerahkan kembali tanah yang diberikan dengan Hak Guna Bangunan kepada Negara, pemegang Hak Pengelolaan atau pemegang Hak Milik sesudah Hak Guna Bangunan itu hapus; dan

5. Menyerahan sertifikat Hak Guna Bangunan yang telah hapus kepada Kepala Kantor Pertanahan.

Pada Pasal 31 tentang kewajiban pemegang Hak Guna Bangunan dinyatakan bahwa jika tanah Hak Guna Bangunan karena keadaan geografis atau lingkungan atau sebab - sebab lain letaknya sedemikian rupa sehingga mengurung atau menutup pekarangan atau bidang tanah lain dari lintas umum atau jalan air, pemegang Hak Guna Bangunan wajib memberikan jalan keluar atau jalan air atau kemudahan lain bagi pekarangan atau bidang tanah yang terkurung itu.

Penjelasan substansi Pasal 31 adalah Pemberian Hak Guna Bangunan tidak boleh mengakibatkan tertutupnya penggunaan dari segi fisik tanah yang terkurung oleh tanah Hak Guna Bangunan itu. Oleh karena itu pemegang Hak Guna Bangunan wajib memberikan kesempatan kepada pemegang hak atas tanah yang terkurung memiliki akses yang diperlukan.

Dapat disimpulkan dari makna substansi ketentuan pasal di atas adalah pemegang Hak Guna Bangunan tidak boleh merugikan pemegang hak atas tanah lainnya dan penggunaannya tidak boleh sampai mengganggu bidang tanah lain dari lintas umum atau jalan air.

\section{B. Hak Milik}

Hak Milik dapat terjadi karena:

1. Ketentuan Hukum Adat

Menurut hukum adat, Hak Milik dapat terjadi karena proses pertumbuhan tanah ditepi sungai pinggir laut. Pertumbuhan ini menciptakan tanah baru yang disebut "lidah tanah". Lidah tanah ini biasanya menjadi milik yang mempunyai tanah yang berbatasan. Selain itu dapat terjadi karena pembukaan tanah, misalnya yang semula hutan, dibuka atau dikerjakan oleh seseorang, kemudian tercipta hak pakai. Sehingga hak pakai ini lama kelamaan bisa tumbuh menjadi hak milik.

2. Ketentuan konversi menurut UUPA, sejak tanggal 24 September 1960, semua hak-hak atas tanah yang ada, diubah jadi salah satu hak baru. Perubahan ini disebut Konversi. Hak-hak atas tanah yang dikonversi menjadi Hak Milik adalah yang berasal dari:

a. Hak eigendom kepunyaan badan-badan hukum yang memenuhi syarat yaitu badan hukum yang ditunjuk oleh Pemerintah seperti yang diatur dalam PP No 38 Tahun 1963

b. Hak eigendom yang pada 
tanggal 24 September 1960, dipunyai oleh WNI tunggal dan dalam waktu 6 (enam) bulan datang membuktikan kewarganegaraannya.

c. Hak Milik Indonesia dan hakhak semacam itu, yang pada tanggal 24 September 1960, dipunyai WNI atau badan hukum yang mempunyai syarat sebagai subyek Hak Milik

d. Hak Gogolan yang bersifat tetap.

3. Penetapan Pemerintah

Pemerintah memberikan Hak Milik atas tanah secara langsung dari tanah yang dikuasai oleh Negara berdasarkan suatu permohonan. Selain memberikan Hak Milik yang baru sama sekali, juga dapat memberikan Hak Milik berdasarkan perubahan suatu hak yang sudah ada, umpamanya Hak Guna Usaha, Hak Guna Bangunan dan Hak Pakai.Pemberian Hak Milik, Hak Guna Bangunan dan Hak Pakai yang berasal dari tanah yang langsung dikuasai oleh Negara (tanah Negara) dilakukan dengan Penetapan Pemerintah dengan mengeluarkan Surat Keputusan Pemberian Hak Atas Tanah (SKPH).

\section{Pengaturan Hukum Tentang Hak Dan Kewajiban Pemegang Hak Guna Bangunan Dan Hak Milik Dalam Hukum Pertanahan Indonesia}

Pemberian Hak Guna

Bangunan di atas tanah Hak Milik yang ada selama ini didasarkan pada perjanjian sewa-menyewa dan akta pemberian Hak Guna Bangunan di atas tanah hak milik. Hanya dengan kedua perjanjian dasar tersebut sering dirasa belum mencerminkan kepentingan-kepentingan para pihak, baik pihak pemegang Hak Milik atau pihak yang akan mendapatkan Hak Guna Bangunan. Keputusan Presiden Republik Indonesia, sesuai persyaratan sebagaimana dimaksud dalam Pasal 24 ayat (4) dan Pasal 44 Peraturan Pemerintah Nomor 40 Tahun 1996 seharusnya memang seharusnya ada guna mengatur tata cara pemberian Hak Guna Bangunan di atas tanah hak milik. Karena dalam akta pemberian Hak Guna Bangunan di atas tanah Hak Milik sudah tercantum klausul atau pasalpasal yang baku, dalam artian tidak dapat diubah ataupun ditambahkan sesuka hati para pihak. Jadi pasalpasal yang masih bisa ditambahkan untuk mengakomodasi kepentingan pemegang Hak Guna Bangunan dan pemegang Hak Milik ada pada perjanjian pendahuluan, dapat berupa perjanjian sewa-menyewa ataupun perjanjian biasa. Mengenai hak-hak bagi pemegang Hak Guna Bangunan dan pemegang Hak Milik memang sudah diungkapkan pada perjanjian sewa-menyewa atau pada akta pemegang Hak Guna Bangunan dan pemegang hak milik.

Ketentuan tersebut menjelaskan bahwa pemberian Hak Guna Bangunan di atas tanah Hak Milik lahir pada saat dibuatnya akta pemberian Hak Guna Bangunan tersebut oleh Pejabat Pembuat AktaTanah (PPAT).

Pendaftaran yang dilakukan adalah hanya untukmengikat pihak ketiga. Ketentuan ini berbeda dari pemberian Hak Opstal di atas eigendom barang tidak bergerak, khususnya tanahmenurut BW/Kitab undang-undang hukum perdata. Pandangan Kitab Undang-Undang Hukum Perdata, hak opstal barulahir pada saat didaftarkan menurut ketentuan Pasal 620 BW/Kitab Undang-Undang Hukum Perdata. 


\section{Proses Pemberian Hak Guna Bangunan Di Atas Hak Milik}

Dalam peraturan perundangundangan ditetapkan bahwa ada 4 cara untuk memperoleh hak atas tanah, di antaranya:

\section{Penetapan Pemerintah}

Perolehan ha katas tanah yang berasal dari tanah Negara atau tanah Hak Pengelolaan melalui pemberian ha katas tanah Negara atau tanah Hak Pengelolaan kepada Menteri Agraria dan Tata Ruang/ Kepala Badan Pertanahan Nasional Republik Indonesia melalui Kepala Kantor Pertanahan Kabupaten/Kota. Bentuk Penetapan Pemerintah dalam perolehan ha katas tanah adalah Surat Keputusan Pemberian Hak (SKPH).

2. Ketentuan Undang-Undang

(Penegasan Konversi)

Perolehan hak atas tanah ini terjadi karena ketentuan UndangUndang melalui permohonan penegasan konversi (perubahan status hak atas tanah) yang berasal dari bekas tanah milik adat. Untuk bekas hak barat atas tanah penegasan konversinya berakhir tanggal 20 September 1980. Permohonan penegasan konversi (perubahan status ha katas tanah) atas dari bekas tanah milik adat diajukan oleh pemohon kepada Kepala Kantor Pertanahan Kabupaten/Kota setempat.

\section{Peralihan Hak}

Perolehan ha katas tanah ini terjadi dalam bentuk beralih melalui pewarisan, dan dalam bentuk dialihkan melalui jual beli, tukar menukar, hibah, pemasukan dalam modal perusahaan (inbreng), atau lelang. Pendaftaran peralihan ha katas tanah dilaksanakan oleh Kantor Pertanahan Kabupaten/Kota.
4. Pemberian HakPerolehan Hak Guna Bangunan atau Hak Pakai yang berasal dari tanah Hak Milik yang dibuktikan dengan Akta Pemberian Hak Guna Bangunan atau Hak Pakai Atas Tanah Hak Milik yang dibuat oleh Pejabat Pembuat Akta Tanah (PPAT) yang berwenang. Pemberian Hak Guna Bangunan atau Hak Pakai tanah atas Hak Milik didaftarkan ke Kantor Pertanahan Kabupaten Kota setempat untuk memenuhi asa terbuka dalam pendaftaran tanah.

Dari aspek penggunaan atau pemanfaatan tanahnya, hakatas tanah dibagi menjadi 2, yakni:

a. Hak atas tanah untuk keperluan mendirikan bangunan

Di atas ha katas tanah didirikan bangunan oleh pemegang haknya, misalnya berupa rumah tempat tinggal atau hunian, rumah susun, rumah toko, rumah kantor, rumah sakit, rumah makan, toko, kantor, pabrik, gudang, hotel, pasar/plasa/mall, gedung pendidikan, gedung peribadatan, gedung pertemuan, gedung olahraga, terminal, pelabuhan, stasiun, Bandar udara.

b. Hak atas tanah untuk keperluan bukan mendirikan bangunan

Hak atas tanah dimanfaatkan atau diusahakan untuk keperluan pertanian, perikanan, peternakan, atau perkebunan.

\section{G. PENUTUP}

\section{A. Kesimpulan}

Dari hasil penelitian di bab sebelumnya, maka dapat ditarik beberapa poin kesimpulan sebagai berikut:

1. Pengaturan hukum tentang hak pemegang Hak Guna Bangunandiatur dalam pasal 32 Peraturan Pemerintah Nomor 40 
Tahun 1996. Sementara kewajiban pemegang Hak Guna Bangunandiatur dalam Pasal 30 Peraturan Pemerintah Nomor 340 Tahun 1996. Sedangkan Pengaturan hukum tentang hak pemegangHak Milik dalam hukum pertanahan Indonesia diatur dalam pasal 4 ayat (2) UUPA, dan kewajiban pemegangHak Milik dalam hukum pertanahan Indonesia diatur dalam pasal 15 UUPA.

2. Pengaturan hukum pemberianHak Guna Bangunan diatas tanah Hak Milik diatur dalam Pasal 24 Peraturan Pemerintah Nomor 40 Tahun 1996, yakni pemberian Hak Guna Bangunan di atas tanah Hak Milik lahir pada saat dibuatnya akta pemberian Hak Guna Bangunan tersebut oleh Pejabat Pembuat Akta Tanah (PPAT). Jangka waktu pemberian Hak Guna Bangunan diatur dalam Pasal 25 Peraturan Pemerintah Nomor 40 Tahun 1996, yakni paling lama tiga puluh tahun dan dapat diperpanjang untuk jangka waktu paling lama dua puluh tahun dan kepada bekas pemegang hak dapat diberikan pembaharuan Hak Guna Bangunan di atas tanah yang sama.

\section{B. Saran}

1. Untuk Pemerintah

a. Dalam pemberian Hak Guna Bangunan di atas tanah Hak Milik harus mencerminkan rasa keadilan, yang pemberiannya selain berfungsi sebagai penghambat monopoli oleh pihak-pihak tertentu, sebaiknya juga memperhatikan rasa keadilan, dalam hal ini memperhatikan kepentingan pemegang hak milik.

b. Perlindungan hukum terhadap pemegang Hak Milik dalam hal ini masyarakat pertamatama memerlukan tersedianya perangkat hukum tertulis lengkap dan jelas yang dilaksanakan secara konsisten sesuai dengan jiwa dan isi ketentuannya, oleh karena itu diharapkan peraturan perundang-undangan yang ada di Indonesia terutama berkaitan di bidang pertanahan perlu direvisi kembali sesuai dengan keadaan dan kondisi sekarang ini.

2. Untuk Masyarakat

Pemegang Hak Guna Bangunan dan pemegang Hak Milik diharapkan dapat mengetahui hak-hak dan kewajiban masing-masing atas bangunan dan tanah yang dimiliki agar tidak terjadi perselisihan yang dikarenakan Hak Milik atau Hak Guna Bangunan hapus tanpa diketahui penyebabnya atau perselisihan lain yang tidak diinginkan.

\section{H. DAFTAR BACAAN}

\section{Buku-buku}

Marzuki,Peter Mahmud, Penelitian Hukum, Kencana Prenada Media Group, Jakarta, 2011.

Siahaan,Marihot Pahala, Bea Perolehan Hak Atas Tanah dan Bangunan, Raja Grafindo Persada, Jakarta, 2003.

Soerjono Soekanto dan Sri Mahmudji, Penelitian Hukum Normatif, Raja Grafindo Persada, Jakarta, 2004, Cetakan ke-8. 